\title{
Celebrating the Yukon's First World War Hero Joe Boyle: Queen Marie, Romania \& Film
}

Max Fraser

Yukon Film Producer

Abstract: Canadians are lackluster when it comes to celebrating our heroes. Even Pierre Berton didn't tackle what just might be the Yukon's biggest story ever-that of the incredible Klondike Joe Boyle, whose exploits in the First World War are worthy of a major motion picture. This paper discusses the life of this dynamic man, focusing in particular on his biographers' explorations of the nature of his relationship with Marie of Edinburgh, Queen of Romania. The unexpected romance notwithtanding, Joe Boyle's tremendous story is one of huge accomplishments by a Yukoner that deserves more widespread recognition. This article is part of a special collection of papers originally presented at a conference on "The North and the First World War," held May 2016 in Whitehorse, Yukon. 
Here we are, one hundred years after some truly amazing and momentous accomplishments by Yukoners in what may be the greatest conflict this world has ever known and what do we have to show for it? Not a lot, frankly. Although there have been books and magazine articles and, in some cases, scholarly works, even curriculum materials and at least one colouring book, there have been few television shows and movies about our heroes-Joe Boyle, Martha and George Black, Robert Service-and TV and film are what it takes, usually, to make something popular, to become imprinted in the public mind, to become, as it were, a household wordalthough, as a former book publisher in the Yukon, I know as much as anyone about the value of a good book to the people who read it, and also to our society and our local and national culture; and I'm very glad to see that books are holding their own in the digital age.

Great technological change was occurring with modern communications about 100 years ago. Telegraph was being supplemented and replaced by telephone. Moving pictures, then talking pictures, then radio were coming into the fore. National governments responded. Canada created two vital organizations in the 1930s to record and present Canadian culture to Canadians-Canadian Broadcasting Corporation (CBC) Radio in 1936 and the National Film Board (NFB) in 1939. Ostensibly, this media was to portray Canada to Canadians when faced with the overwhelming quantity of American media beaming across the border. In the 1950s, CBC Television was created as that medium came into peoples' homes, broadening to a great extent the reach of movie houses and radio with a wide range of programming-news, soaps, comedy, drama, and game shows. Television represented a whole new world for motion pictures, which to that point had been confined to movie theatres. The screens were now in people's homes. (And today we carry video with us on our "phones" everywhere we go.) This new form evolved quickly from what began as basically radio with pictures; and CBC TV brought its own innovations along with obvious copycat versions of popular American programs.

One of the Yukon's most prolific and well-known authors, Pierre Berton, can credit a lot of his success to his place in television in the 1950s - as a regular panelist on the show Front Page Challenge. This gave him a huge profile until 1995 when the show ended. He had a regular spot on the panel because of his skill as a writer and storyteller. In 1954 he published his first book about the Klondike, The Golden Trail: The Story 
of the Klondike Gold Rush. This was followed in 1957 by the NFB film City of Gold, which Berton narrated. That documentary segued nicely with the publication of one of his most well-known works: Klondike: The Last Great Gold Rush 1986-1899, which was published in 1958.

So Berton's Klondike was an obvious candidate for a TV series. In his memoir, Life and Times, Berton related his disappointing encounter with Hollywood as it squeezed out thirteen episodes from the book for a TV series, which, I gather, was not well done, nor well received; it was just another cowboy show set and shot in California.

The Klondike, of course, was first and most notably popularized by Charlie Chaplin in his 1925 movie The Gold Rush. A string of gold rush themed movies followed and it became its own genre, with spinoffs in comic books, then radio, which became widespread in the 1930s. These brought to life Sergeant Preston of the Yukon, at first as a very popular radio series in the 1930s and 1940s and then as a TV show in the 1950s and 1960s. So while the Yukon was being popularized, our heroes were not. Unless you were a Hollywood Mountie.

In 1962 Pierre Berton penned an article for the Toronto Star titled "A Canadian Hero for the TV Screen?" It was about Joe Boyle:

It is a common platitude in this country that we have no great heroic figures in our past on which to base the kind of mythology that surrounds a Wyatt Earp or a Davey Crockett or half a hundred other US folk heroes. Television and magazine writers, searching for two-fisted Canadian themes, come up with the Mounties and exit. There has not yet been a TV action serial starring a Canadian and the general belief is that we've never produced a Canadian worth such a build-up. This is nonsense, and today I propose to quote chapter and verse to prove it. It is my contention that, had Joseph Whiteside Boyle been born south of the border, he would by now have been a central figure in both motion pictures and television. 
I'm a huge fan of Joe Boyle and agree with Berton who laid out in that article a substantial amount of information about Boyle's real-life adventures to back his case:

- Joe Boyle came from modest beginnings in Woodstock, Ontario to achieve near-royal status as undisputed King of the Klondike and Dawson's leading citizen.

- He industrialized mining in the goldfields with giant dredges, huge power projects, and railways, literally moving mountains and rivers in the fashion of a god.

- In 1914, Boyle was one of Dawson's leading citizens when war broke out. Though at age forty-six he was too old to enlist, Joe Boyle made up his mind-he would help win that war. Singlehandedly if necessary.

- So he immediately financed a machine gun detachment of fifty men, which left Dawson in October 1914.

- In return, in the custom of the day, Boyle received a commission in the militia. And of course he made the most of it. He got himself a uniform and decorated it with badges made of Klondike gold. Technically an honourary lieutenant colonel, he soon became known as "Colonel Boyle," while conducting himself as if he ran the whole army.

What drove Joe Boyle to do what he did? Clearly he was a patriot, but so were many others around him. I suspect he was having a mid-life crisis of sorts. By that point in his life, he had accomplished all he had set out to do. There were no more gigantic challenges. No doubt he was looking for something new and different and big, really big: something he could get excited about and sink his teeth into. Part of his story, and it may be true, is that he was looking to opportunities in Russia for gold mining. That's what he told people when he boarded that steamboat in Dawson on 17 July 1916, the start of his trip to Europe. His real goal was to become involved directly and personally in the war effort.

At the time, I think even Joe Boyle had no idea of what direction his future would take. That he would go on to:

- Become the Yukon's most decorated hero of the First World War, earning medals from Romania, Russia, France, and Britain-and more than most other medal recipients in Canada. 
- Perform a string of heroics, putting his own life in danger to save others, including a group of captive Romanians in desperate circumstances, earning him the title "the Saviour of Romania." That earned him a gift of land and the title of Duke.

- Organize and operate a massive spy network for the British Secret Service-more than 450 agents across central and eastern Europe.

- Reorganize and manage the Russian railway system in Europe.

- Advise the Russian military on winning tactics against the Central Powers.

- Negotiate the first peace treaty of the First World War-between Romania and Russia.

- Engage in a series of exploits the stuff of fiction, along the lines of Indiana Jones and James Bond.

Most of all, Joe had an unexpected love affair with a Queen-Marie of Edinburgh, Queen of Romania, who relied on Joe and his strength to survive and, ultimately, triumph over the extreme hardship and adversity that came with war.

Joe Boyle did not go to Europe looking for love. But that's what he found. After two marriages, one of which he abandoned in Canada, Joe finally met, in the deep turmoil of war, his true love, his soul mate, a woman unlike any other he had ever met before.

Marie of Edinburgh was a British royal, married to the Romanian throne years before when she was only seventeen. A granddaughter of Queen Victoria, once promised to the man who now was King of England, she was in mid-life, as was Joe. Marie now led her adopted country, which was suffering badly and cut off from the allies. No one could get through to help them, until Joe Boyle came along to save the day in the manner of a classic rescuing hero.

Joe was in Russia to fix the railway system and keep that wavering country in the war. A million Russian soldiers were in Romania without enough food and supplies. Joe was tasked with a rescue mission, which he accomplished mightily, earning him a medal and high praise from the Russian government. They put him in charge of all their railways in Europe. In October came the Bolshevik Revolution. Lenin and Trotsky found Joe useful, and non-threatening, and kept him on.

By that time, Romania had been overrun for the most part by the Central Powers-Germany, Austria, and Hungary. The government and royal family had fled to the provincial capital of Jassy. They had sent all 
their valuables to the Kremlin in Moscow for safekeeping: their gold, paper currency, archives, and royal jewels. Now the Communists were in power and the Romanians wanted their stuff back. They called on Joe, who said he'd do it.

So he put together a long train of relief supplies for Romania, and got out of the Kremlin everything of the Romanians that he could. His train set out on a wild adventure. In the deep dark cold of winter, Joe's rain crossed more than 800 miles $(1,287 \mathrm{~km})$ of the uncontrolled, war-torn frontier of Russia and the Ukraine, encountering barriers all the way. Enemies were everywhere, either bandits, revolutionaries, enemy agents, or renegade soldiers loyal either to the Czar or Bolshevism. After an eight-day Indiana Jones style adventure, Joe's train rolled into Romania, triumphant, on Christmas Eve. The best news the Romanians had had in six months.

Marie was a queen who needed a rescuer, a gallant champion who would save her and her country. That's when Joe Boyle entered her life. Marie was an elegant, beautiful, and regal royal, fighting for survival. She had given birth to the requisite number of royal children, and taken a number of romantic companions just as her husband, King Ferdinand, had taken many women before settling with one mistress. Ferdinand was not a strong leader and Marie was the real power in the country. She ruled with Ferdinand and a Romanian prince, Barbu Stirbey, who was also Marie's chief love interest and father of at least one of her children.

As the enemy closed in, and the few remaining allies fled, only one person said he'd stay to defend Marie and her country: her new friend and source of strength and confidence, Joe Boyle. After the war ended, Joe kept working for Romania and didn't return to Canada or his home in the Yukon. At the Paris Peace Conference in 1919, he persuaded Canada to provide the incredible sum of $\$ 25$ million as a loan to help the damaged Romania recover. He also arranged aid from the United States and other countries for Marie's adopted homeland.

As is the fate of star-crossed lovers, Joe's relationship with Marie had to end, for she was a Queen and he was a commoner. Romanians looked the other way during the war, but with the peace came a change in attitude and level of tolerance about the closeness of this Canadian adventurer to their queen. Joe Boyle kept in touch with Marie at a distance, eventually dying in London in 1923 at the age of fifty-six, after a second stroke took all his strength. He had worn himself out. After he passed, legend has it that every year on the anniversary of his death a woman in black wearing a long veil visited his grave. It is said this was Marie, for after her death in 1938 the visits to Joe's grave stopped. In the 1980s, a group in Woodstock, 
Ontario brought back Joe's remains from England. And that's where they lie to this day.

I find it ironic as well as mystifying that, more than fifty years after Berton made his point, there has yet to be a movie or TV series about our hero Joe. I only know of one-a 2005 Romanian-language documentary (translated "The Hero and the Queen") produced by Raul Dudnic and aired on OMNI-TV, the Canadian multilingual and multicultural channel. The film tells of Joe's time in Romania and deals briefly with his romance with their Queen.

I have spoken to others in the Canadian film and TV business who have tried to sell the Joe story and bring it to the TV or movie screen. Like me, they love the story and have written scripts, arced episodes and series, and pitched the project no doubt more than once to the networks but, for a variety of reasons I can only guess at, have not been able to get a show green lit for production. So they give up and move on to do another show that the broadcasters will finance. And this is something of a mystery to me, a mystery I must solve or find a way to go around as I pursue my quest to put the Joe Boyle story on the big screen.

No doubt it is something-as Berton said-to do with how we Canadians regard and treat our heroes. We do things differently than the Americans and the Brits, who seem to have no shame and certainly no shortage of enthusiasm for finding or inventing or exaggerating their heroes and their exploits. It must have a lot to do with how they see themselves not just as people but as nations: their national narratives need more heroes because they are playing a bigger game on the international stage. And somehow they must believe, as well as portray, that their countries are bigger and better than all the rest. Whatever the case, it has become painfully obvious that one of the challenges about championing our hero Joe is right here in our own backyard.

It is difficult to promote the legend and memory of one of Yukon's own to audiences across the country and around the world when Yukoners themselves do not. We really must practice what we preach, me included. I'm embarrassed to say that I had to be told about Joe by an Englishman who was working in Canada. We met at a reception at the Banff World Television Festival. We told each other where we were from and he said, "Oh, you're from the Yukon? You must know then all about Joe Boyle?" I mumbled a few words as I took a sip from my drink, and encouraged him to continue. He grew up near the cemetery where Joe Boyle was buried in London at Hampton Hill. He kept talking, I kept listening. And, after this historic revelation, when I got home I started looking for information 
about Joe Boyle. I found two good books on Joe, some very good ones about Queen Marie, and a couple of not so good ones.

On my mission to discover the legacy of Joe Boyle, I went to Dawson City, where Joe had made his millions in the goldfields. I looked around. All around. Nowhere in the town can you find one item on public display about our hero Joe and his accomplishments. No building, no plaque, no monument, no hotel, restaurant, or bar. One has to go to Bear Creek Compound to see Joe Boyle's house - in a huge state of disrepair, sadly ${ }^{1}-$ or out to Bonanza Creek to see one of Joe's giant dredges, Canadian No. 4. There is a small plaque there, designed by Historic Sites and Monuments Board of Canada, noting that Joe Boyle is a National Historic Person. On their website is a brief write-up about Joe's accomplishments.

There has been more talk about Joe in Dawson over the last few years. Recently, the Dawson City branch of the Royal Canadian Legion put together a small display in their hall, though they cannot afford to staff an office that is open to the public. And recently there has been talk of a monument being erected in the community. The museum, I'm glad to report, plans a new exhibit about our hero Joe. There is a hope of even bigger and better things, and a desire to share with Woodstock, Ontario the ongoing celebration of this man's huge legacy.

In Woodstock, there is a lot more about Joe Boyle than you see in Dawson, including an exhibit, albeit a small one, in the municipality's museum. There is a collection of papers, records, and photos at the Oxford Historical Society as well as in the Woodstock Public Library-some fine institutions that are doing their bit to preserve and commemorate this history. And in the Presbyterian Cemetery a giant monument marks Joe's final resting place. In Woodstock, we find the heart of the memory of Joe Boyle. Thank goodness.

In my quest to make a documentary or feature film about Joe Boyle, I've had to face the same challenge as others before me: Boyle's one lifetime is too big, too packed, for one show. In the hands of excellent television scriptwriters, it could be a very long-running series. Certainly a documentary series. Or a series of feature films.

I've come up with a new approach to a documentary series for the story of Joe in the war, and I'm pitching it to broadcasters. While no one has yet opened their cheque book, I've been encouraged to develop my ideas further and come back. So I'm doing that.

But more than anything, what I want to see is a big screen feature film, with the epic romance of Joe and Marie set against the backdrop 
of the world war. A giant cinematic blockbuster with great actors, great production values, and a budget worthy of the topic and the two main characters.

If Pierre Berton were here today I would tell him it should not be a Hollywood film because the Yanks would turn our Canadian hero into an American. Hollywood botched the TV series Klondike, and it could ruin this great story too.

I want this film to be made by Canadians, but with British partners, because they are just so very good at historical drama, and also because they have a huge audience for films to do with the royal family. And Marie was a British royal, a granddaughter of Queen Victoria.

So we have a great recipe for an epic romance: Two great characters, both larger than life, who meet in desperate times. She, the damsel in distress; He, the rescuing prince. They are drawn to one another, but torn apart frequently by duty and circumstance. Against all odds, they fall in love. But their love is star-crossed and cannot last because, when all is said and done, he is a commoner, and she is a Queen.

A challenge to getting such a production off the ground is the question of the precise nature of their relationship; it is in some dispute, and the facts of the matter are difficult to discern. Others have tried and we may never be able to say, with confidence, what was the true nature of their relationship in their private moments, but I'm happy to share with you some of my research to this point.

There are two schools of thought. Some say Joe and Marie enjoyed a strong friendship, that it was duty that drew Joe to Marie's aid and service, and what Marie had for Joe was admiration and gratitude, out of which grew a strong devotion, but that they were never lovers. Others, including Boyle's most recent biographer, say they were lovers, that these two mature persons with considerable life experience enjoyed a physical, sexual relationship that contributed to the deep bond that formed between them, which lasted until their deaths.

Where do we look for information about this and what can we rely on? The first book to deal with the subject was written by Marie herself. Published in 1935, Ordeal-The Story of My Life is her autobiography that focuses mostly on her experiences in the First World War. Marie was a prolific writer and was published widely in several American magazines. She was very well known in Europe and North America in the time between the wars. Her book draws extensively on her diary from the time she first met Joe Boyle: 
Although full of anguish, I had a busy day and made the acquaintance of a very interesting Canadian, a certain Colonel Boyle, who is working for us in Russia, trying to better our situation, and especially our transport. A curiously fascinating man who is afraid of nothing, and who by his extraordinary force of will and fearlessness, manages to get through everywhere. A real Jack London type. (312)

Colonel Boyle, who had been dining with us, came and sat with me, and I tried to let myself be steeled by the man's relentless energy, tried to absorb some of the quiet force which emanates from him. I poured my heart out to him during those hours and he sat with me. I do not know all that I told him, the memory is a blur, but I made a clean breast of all my grief and when he left me and I said that everyone was forsaking me, he answered very quietly "But I won't," and the grip of his hand was as strong as iron. (321)

Being myself entirely unresigned and exceedingly rebellious, it was natural that an irresistible sympathy should spring up between us; we understood each other from the first moment we clasped hands, as though we had never been strangers. His advice was strong, brave, stimulating, sometimes a little ruthless, but always invigorating. He admired me for my strength of resistance, and had faith in my tenacity, and this belief he had in me, kept me strong; I can honestly say that during that dark period of my life, Joe Boyle often kept me from despairing. (343)

The next book is a biography of Joe Boyle written by Kim Beattie. Called Brother, There's A Man! It was published in 1940, seventeen years after Boyle's death, and two years after the death of Marie in 1938. Remarkably, the book features a foreword by Marie, which was passed to the author by the British Foreign Office. She had written it just before her death. In that foreword, Marie wrote:

... all at once Joe Boyle was there, a stranger, and yet, somehow, not a stranger, because I seemed to have been waiting for him ... (v)

My heart becomes soft when I think of him, soft with a great wistfulness and with an aching longing. (vi) 
Beattie's book has been criticized by many, mainly because of its lack of references and attribution of statements it has put forward as facts. So while it's an exciting read, and gives readers something to go on, it has been undermined by its own lack of rigour when it comes to separating fact from fiction. Beattie's book comments little on the relationship between Joe and Marie, and accepts that theirs was a strong friendship.

The most authoritative biography of Joe Boyle was written by William Rodney of Victoria, British Columbia. Published in 1974, Joe Boyle-King of the Klondike is thoroughly researched and referenced and, as a result, highly credible. Rodney found evidence of love, at least on the part of Joe towards Marie, but does not say there was a romantic relationship between them. Rodney is among those critical of Beattie, and he criticized the suppositions of others about the Joe-Marie relationship:

From that brief encounter with Boyle [their first meeting in March 1918] grew a friendship based upon mutual respect and admiration that gradually developed into an affair of courtly love with the classic elements of a fairy tale. The meeting, however, initiated gossip and rumour which, through persistent repetition, transformed the relationship between Queen and commoner into a carnal affair initiated by Marie. (171)

Rodney chronicles how traumatized was Marie when she heard that Boyle had suffered a stroke. She immediately ensured he got the best of care. As soon as Joe could be safely moved out of hospital, she brought him to her country retreat where Marie personally nursed him back to health, tending to him at least twice daily over a period of six weeks. As one might imagine, they grew very close during this time. Boyle formed strong friendships with Marie's children, playing with them often and reciting Robert Service poetry, earning the new family name "Uncle Joe." Marie's diary is often quoted about how much she admired and how fond she was of Boyle.

Yes, I set Boyle apart amongst men and I feel honoured to have met him. Joe Boyle the King of the Klondike, he is a man in a million and I thank God, Providence, Fate, whatever strange power put him on my road, never did he have a greater admirer than I, nor one who feels more grateful towards him, because of what he has done and is doing. I am grateful to him for existing. Our roads may part again but I will never forget what I have felt about him; it 
is one of the good things in my life ... It seems incredible to him that the only woman he should finally have found as companion and co-worker should be a queen. It seems a strange fate. (205)

Rodney concludes that Boyle's admiration and affection for the Queen grew into love.

During those busy but relatively tranquil days in almost idyllic surroundings Boyle's admiration for Marie gradually turned from a benign affection into a deep and abiding love.

Rodney would not go so far as to say that Marie's feelings for Joe were reciprocal, as it could not be substantiated. At the same time, the biographer didn't expect Marie to commit such things to paper.

In his (later) letters to the Queen, Boyle expressed himself with candor and customary directness. Marie, aware of her position, did not commit her feelings to paper with the same frankness. It was she who, from the time of Boyle's illness, established the terms upon which their relationship flourished, diverting it from the physical plane to a more exalted spiritual level. (261)

In his epilogue, Rodney finally acknowledges the sexually liberal nature of the Romanian court, and the accepted infidelity of King Ferdinand to his wife and Queen, Marie. He implied that Marie too had her share of lovers but the author would not state so categorically.

Marie felt Boyle's death acutely ... The depth of her feeling for him emerges in successive entries in her diary, and in long letters ... In her diary she comes as close as possible to admitting that she loved him. But as a Queen, not even in the privacy of her journal did she make that ultimate admission. (308)

Almost ten years after Rodney, a new book about Boyle was published by author Len Taylor, who was among those fans of Joe Boyle who helped organize the return of his remains from England to his hometown of Woodstock, Ontario. The book came out in 1983, around the same time as the reinternment. The Sourdough and the Queen-the Many Lives of Joe 
Boyle builds on Rodney's research and has the benefit of new material uncovered by Taylor in Northern Ireland. While it suffers from a lack of detailed references, his research files are available at the Woodstock Public Library.

Taylor grew up in Woodstock and, while in England with the Canadian Army during the Second World War, he followed the Joe Boyle story, including a visit to Joe's grave at Hampton Hill.

Taylor's new research came in the form of many of Joe Boyle's papers that had been left at the public records office in Upper Buckna, County Antrim, Northern Ireland, which had kept them safe all that time until Taylor went looking. Boyle had occasionally visited his Irish relations in the area during his time in England.

Unlike Rodney, Taylor also had the benefit of spending a number of days in conversation with Flora Boyle about her father. Years after her father's death, Flora was visited by Marie during the latter's visit to North America, and Marie spoke at length about their time together. Flora never wrote about what had been said to her by the Queen in private, but Taylor no doubt was influenced by what he heard from Flora in terms of his approach to coming to grips with what kind of man Flora's father actually was and what was the true nature of his relationship with Marie. So when Taylor states his conclusion that Marie and Joe had a physical, romantic relationship, we owe it a great deal of credibility:

One thing is certain. In those few weeks of Romanian spring the relationship between Boyle and Marie deepened. That they became lovers seems certain. Both were fullblooded, passionate individuals who made their own rules. They were mature enough to understand the rewards and penalties of such a relationship and wise enough to risk them. (287)

On the heels of Taylor's book came a credible, comprehensive biography of Marie. Published in 1984, Hannah Pakula's The Last Romantic is thorough, marked by its extensive research and complete index. This author has made a name for herself producing a trio of very readable, well-documented biographies of women in history. As well as The Last Romantic, Pakula wrote the biography of Madame Chiang Kai-Shek in The Last Empress and then a volume about another British royal, The Empress Frederick, mother of Kaiser Wilhelm and wife of the crown prince of Prussia, in An Uncommon Woman. With Pakula, we finally have a wellresearched perspective of a woman into the life and times of this grand character Marie, including her relationship with Joe and her other lovers. 
Thankfully, this independent biography expands significantly on Marie's own story of her life published fifty years earlier. Pakula describes how Marie became estranged from her husband not long into the marriage, which took place when she was only seventeen. Ferdinand took a number of lovers and Marie's first substantial extramarital affair was with Waldorf Astor, who at the time was unmarried.

The Romanian court is described as rather liberal in its attitudes towards love and marriage, and Pakula reminds us that throughout history, royals everywhere have married more often for reasons of state than love. Such was the case with Marie. After Astor, Marie's next relationship was long-running. She became attached to Barbo Stirbey, a Romanian prince, and together they ran the country with Ferdinand. At least one of Marie's children is said to have been fathered by Stirbey. Stirbey had his own wife, family, and estate, and, from what Pakula writes, his relationship with Marie was never an issue of consequence.

Marie gained a reputation for having a large sexual appetite and taking on many lovers, but Pakula says this is mainly gossip promoted by enemies - either of her, Ferdinand, Stirbey, or all three. Marie, writes Pakula:

... was looking for a man who could engage her imagination and sense of style-a role for which her husband was comically unsuited. If the three most important men in her life-Barbo Stirbey, Waldorf Astor, and Joseph Boyle-had anything in common, it was that they too were all dedicated if diverse romantics, men who knew how to provide the lady in their lives with a white marble, vine-covered, dramatically situated pedestal. (320)

In fact, Marie was not a sexually passionate woman, although she was high-spirited, flirtatious, and seemingly incapable of verbal restraint. "The moment one is a little different, a little original, they enjoy you, but they tear you to pieces," she wrote to an American friend in 1929. "They imagine that the 'animal' in me must play a big part. They cannot understand 'spirits' ... without an underground of something more lurid. It always astounds me the enormous importance people give to a certain part of life; they uglify and degrade everything by it." (321)

Pakula also relates how deep the relationship between Joe and Marie became while Marie personally cared for Joe during his recovery from 
his stroke in August 1918. Pakula has her own take on what may have happened during that time the giant was stricken.

If their relationship ever moved beyond friendship, as some claim, it was only for a brief moment, brought on by Marie's sympathy for the suffering man. Nevertheless, Boyle fell in love with Marie, and that love changed his life. Three months later he wrote her to say that she had become the central figure of his life. For the first time in his 51 years, Joe Boyle found someone to live for, and from then on he devoted himself to the Queen and her family. (247)

It was more than two decades after the credible work of Taylor and Pakula before anything new was written about Joe and Marie. Two notable authors ventured forth with their accounts of this great love story, though not as full biographies, but as parts of larger works.

Margaret MacMillan produced her seminal work Paris 1919-Six Months That Changed the World in 2001, first published in England under the title Peacemakers. She tells the very big story of how the map of Europe was redrawn after the First World War, devoting chapters to each country and its interests including Romania. Her take on Marie is fascinating and somewhat remarkable for its lack of references and attribution, when clearly her work was otherwise the product of considerable research.

Joe Boyle was working the peace conference, taking orders from no one but acting on behalf of Romania. His influence and powers of persuasion were so considerable that he secured a vast amount of aid for Romania's post-war reconstruction from a number of countries including the United States. From Canada, he obtained the incredible sum of \$25 million, which created a unique foundation for the international relations between our two countries ever since. (A lot of that came in aid, and to this day you can see Massey Ferguson tractors in rural Romania.)

Boyle observed that the Romanian prime minister was not winning his case with the Allies for more land for Romania, and so he sent for Marie. MacMillan described the British royal as:

... lovely, vivacious and adultrous. Her new subjects found this endearing. Her lovers included Joe Boyle, the dashing Canadian millionaire miner from the Klondike, and Britaianu's brother-in-law (Stirbey) who fathered, it was said, all of her children except the disastrous one who became King Carol. (133) 
(It is interesting that this author takes issue with the queen being adulterous, but is silent about the similar conduct of the king.)

MacMillan describes Marie's representations to the many influential people at the conference on behalf of her country. Dining with the British Ambassador, Marie asked him how her conversation with American president Wilson should go and:

... whether she should talk about her recent (shopping) purchases or the League of Nations. "Begin with the League of Nations," he advised, "and finish up with the pink chemise. If you were talking to Mr. Lloyd George, you could begin with the pink chemise!" Lloyd George found her "very naughty, but a very clever woman" ...

Her great failure was (American President Woodrow) Wilson. She shocked him at their first meeting by talking about love. Grayson, Wilson's doctor, agreed: "I have never heard a lady talk about such things. I honestly did not know where to look I was so embarrassed." (134)

No matter whose account you believe, Marie made an impression and got results in Paris. Romania got what it wanted, and between the two world wars held its greatest amount of geography, which is one of the many reasons that Marie is regarded so well, even to this day, by the Romanian people.

The most recent take on the subject came in 2004, when Pierre Berton finally wrote about Boyle in his book Prisoners of the North: Portraits of Five Arctic Immortals. He started the book with a chapter on Joe Boyle, and discusses the relationship with Marie.

The ultimate consummation of that unlikely affair was denied them by circumstances over which they had no control. Indeed, much of the fire in his heart may have been fuelled by the lure of the unattainable. For the first time in his life, Boyle, the take-charge man, found himself powerless to act. (61)

Berton cites one of Marie's most powerful statements about Joe, which was written after the great man had died in England. In a twelve page letter to a friend, she wrote that the relationship between she and Joe was: 
something deep, real, strong, I may say holy, based upon a perfect belief, faith and respect ... We clasped hands at the hour of deepest distress and humiliation and nothing could part us in understanding. No one knew his heart better than I. Women played but little part in his life and he had a wealth of love unspent. ... when he had his stroke I was the haven in which he anchored for a while. (64)

What are we to make of all this? We believe what we choose to believe. I have a difficult time believing that Joe and Marie's relationship was strictly platonic, that they never bonded in true romantic fashion, as lovers. I agree with Len Taylor that their relationship was more than just good friends.

In conclusion, here we have a tremendous story about huge accomplishments by a Yukoner that need to be celebrated and commemorated. The romance notwithtanding, what Joe Boyle accomplished deserves more widespread recognition. The stories of Martha and George Black and Robert Service are equally compelling. Let's do our bit here in the Yukon and elsewhere to advance the memory of these great people from our past. Let's create some concrete tributes to their memories and their accomplishments. Let's celebrate our heroes of the First World War, here at home, across the country, and around the world. I'm taking inspiration from many successful people such as Pierre Berton and also Joe Boyle. While I will never claim to be as talented as either man, I do hope to succeed through perseverance, and do what I can to bring the story of Joe and Marie to life on the big screen.

\section{Author}

Max Fraser is a Yukon film producer living in Whitehorse, Yukon.

\section{Notes}

1. Parks Canada has since announced funds to stabilize Boyle's home at Bear Creek.

\section{Bibliography}

Beattie, Kim. Brother, Here's A Man! The Macmillan Company, 1940.

Berton, Pierre. Prisoners of the North. Doubleday Canada, 2004.

Berton, Pierre. "[Column]," Toronto Star, 1962. Reprinted in North, Volume IX, Number 3, May-June 1962. Northern Administration Branch, Department of Northern Affais and National Resources, Ottawa. 